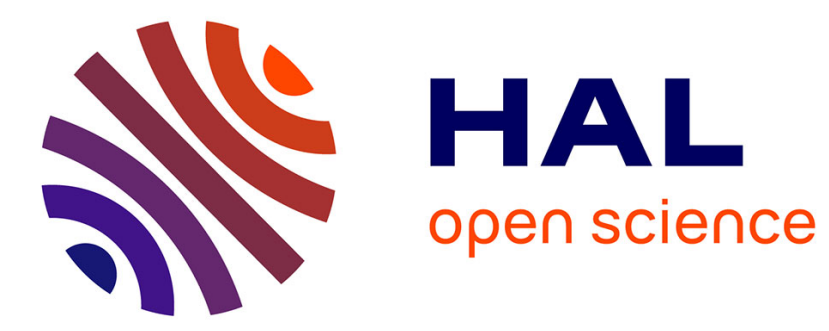

\title{
Quasicrystal Formation in the system Zr75-xTixCu25-yNiy
}

Jean-Louis Soubeyroux, Jean-Marc Pelletier

\section{To cite this version:}

Jean-Louis Soubeyroux, Jean-Marc Pelletier. Quasicrystal Formation in the system Zr75-xTixCu25yNiy. Material Science Forum, 2005, 475-479, pp.3563-3566. hal-00264948

\section{HAL Id: hal-00264948 \\ https://hal.science/hal-00264948}

Submitted on 18 Mar 2008

HAL is a multi-disciplinary open access archive for the deposit and dissemination of scientific research documents, whether they are published or not. The documents may come from teaching and research institutions in France or abroad, or from public or private research centers.
L'archive ouverte pluridisciplinaire HAL, est destinée au dépôt et à la diffusion de documents scientifiques de niveau recherche, publiés ou non, émanant des établissements d'enseignement et de recherche français ou étrangers, des laboratoires publics ou privés. 


\title{
Quasicrystal Formation in the system $\mathrm{Zr}_{75-\mathrm{x}} \mathrm{Ti}_{\mathrm{x}} \mathrm{Cu}_{25-\mathrm{y}} \mathrm{Ni}_{\mathrm{y}}$ Jean-Louis. Soubeyroux ${ }^{1}$, Jean-Marc. Pelletier ${ }^{2}$ \\ ${ }^{1}$ Laboratoire de Cristallographie / CRETA / CNRS, 25 avenue des Martyrs, 38042 \\ Grenoble, France \\ ${ }^{2}$ GEMPPM, INSA Lyon, bâtiment B. Pascal, 20 Avenue A. Einstein, 69621 Villeurbanne, France \\ Jean-Louis.Soubeyroux@grenoble.cnrs.fr, Jean-Marc.Pelletier@insa-lyon.fr
}

Keywords: bulk metallic glass, quasicrystalline phase, in-situ neutron diffraction

\begin{abstract}
During the crystallization study of the bulk metallic glass $\mathrm{Zr}_{46.8} \mathrm{Ti}_{8.2} \mathrm{Cu}_{7.5} \mathrm{Ni}_{10} \mathrm{Be}_{27.5}$ (Vit4) we have demonstrated that the primary crystals appearing during isothermal annealing in the glass region, above $T_{g}$ and before $T_{x}$, were of quasicrystalline nature and beryllium free. The formula of the quasicrystalline phase so obtained and determined by electron techniques (EDX and EELS) was $\mathrm{Zr}_{63} \mathrm{Ti}_{14.4} \mathrm{Ni}_{12.4} \mathrm{Cu}_{10.2}$. We have synthesized phases in the system $\mathrm{Zr}_{75-\mathrm{x}} \mathrm{Ti}_{\mathrm{x}} \mathrm{Cu}_{25-\mathrm{y}} \mathrm{Ni}_{\mathrm{y}}$ by melt spinning and obtained either amorphous or quasicrystalline phases. For the amorphous phases, we have studied the crystallization by in-situ neutron diffraction and obtained quasicrystals as primary crystals. Neutron and X-ray diffraction, DSC studies are presented.
\end{abstract}

\section{Introduction}

Bulk metallic glasses and quasicrystalline phases have attracted a lot of attention this last decade, and among them the family $\mathrm{ZrTiCuNiBe}$ presents the best performances in matter of glass forming ability over cost [1]. However these phases are metastable and several studies deal with the inherent instability of the amorphous state, as this instability modifies the mechanical properties. In particular when these alloys are heated in the supercooled liquid region, decomposition appears and is different for each alloy composition. For the alloy $\mathrm{Zr}_{46.25} \mathrm{Ti}_{8.25} \mathrm{Cu}_{7.5} \mathrm{Ni}_{10} \mathrm{Be}_{27.5}$ (called Vit4), no phase separation appears prior to crystallization and Wanderka et al. [2,3] reported that a quasicrystalline phase is formed in the first step of crystallization, followed by a decomposition of this phase at higher temperatures. Formation of quasicrystals during devitrification of metallic glasses has been also observed in rapidly quenched alloys $\mathrm{Pd}_{60} \mathrm{U}_{20} \mathrm{Si}_{20}$ [4], $\mathrm{Ti}_{45} \mathrm{Zr}_{38} \mathrm{Ni}_{17}$ [5], or bulk metallic glasses $\mathrm{Zr}_{65} \mathrm{Ni}_{10} \mathrm{Ag}_{10} \mathrm{Al}_{7.5} \mathrm{Ni}_{7.5}$ [6], $\mathrm{ZrNiCuAl}$ [7,8] and $\mathrm{ZrTiCuNi}$ [9]. During the crystallization study of the bulk metallic glass $\mathrm{Zr}_{46.8} \mathrm{Ti}_{8.2} \mathrm{Cu}_{7.5} \mathrm{Ni}_{10} \mathrm{Be}_{27.5}$ (Vit4) [10,11] we have demonstrated that the primary crystals appearing during isothermal annealing in the glass region, above $T_{g}$ and before $T_{x}$, were of quasicrystalline nature and beryllium free. The formula of the quasicrystalline phase so obtained and determined by electron techniques (EDX and EELS) was $\mathrm{Zr}_{63} \mathrm{Ti}_{14.4} \mathrm{Ni}_{12.4} \mathrm{Cu}_{10.2}$. So we have extended this study of beryllium free phases to the system $\mathrm{Zr}_{75-}$ ${ }_{x} \mathrm{Ti}_{\mathrm{x}} \mathrm{Cu}_{25-\mathrm{y}} \mathrm{Ni}_{\mathrm{y}}$ in order to study the stability domain of these new quasicrystalline phases.

\section{Experimental details}

Metallic alloys $\mathrm{Zr}_{75-\mathrm{x}} \mathrm{Ti}_{\mathrm{x}} \mathrm{Cu}_{25-\mathrm{y}} \mathrm{Ni}_{\mathrm{y}}$ samples were prepared from a mixture of the pure elements by induction melting in a water-cooled copper crucible under argon gas. The ingots were remelted by electromagnetic levitation several times. Ribbons were obtained by the melt-spinning technique at a constant copper wheel speed of $21 \mathrm{~ms}^{-1}$, injected under argon by a cordierite rectangular nose of 7 by $0.4 \mathrm{~mm}$ and producing ribbons with a thickness of $50 \mu \mathrm{m}$ and a width of $7 \mathrm{~mm}$.

The endothermic and exothermic reactions associated with glass transition, crystallization and melting processes were examined by DSC at different heating rates on a Netzsch DSC 404S calorimeter under a flowing argon atmosphere. Neutron diffraction experiments were performed on the D1B diffractometer of ILL-Grenoble which is equipped with a 400 cells position sensitive 
detector, covering an $80^{\circ}$ 2-theta range, and allowing recording a pattern every 5 minutes. The experiments were performed in a dedicated furnace with a vanadium resistor under a secondary vacuum. The wavelength used was $0.2524 \mathrm{~nm}$. The data presented are corrected of the background, sample container and furnace contributions.

\section{Results and discussion}

The first ribbon produced and analyzed was the composition determined during our study of the decomposition of the Vit4 bulk metallic glass, $\mathrm{Zr}_{63} \mathrm{Ti}_{14.4} \mathrm{Ni}_{12.4} \mathrm{Cu}_{10.2}$ [10]. It is amorphous by $\mathrm{X}$-ray and neutron diffraction. The DSC experiment performed at $2 \mathrm{~K} / \mathrm{min}$ is reported in figure 1a, it shows three exothermic peaks at 576, 609 and $656 \mathrm{~K}$ reported as $\mathrm{Tx}_{1}, \mathrm{Tx}_{2}$ and $\mathrm{Tx}_{3}$ on the figure. We have performed an in-situ neutron diffraction experiment by heating the ribbon between 300 and $670 \mathrm{~K}$. The three dimensional plot is reported in figure $1 b$.

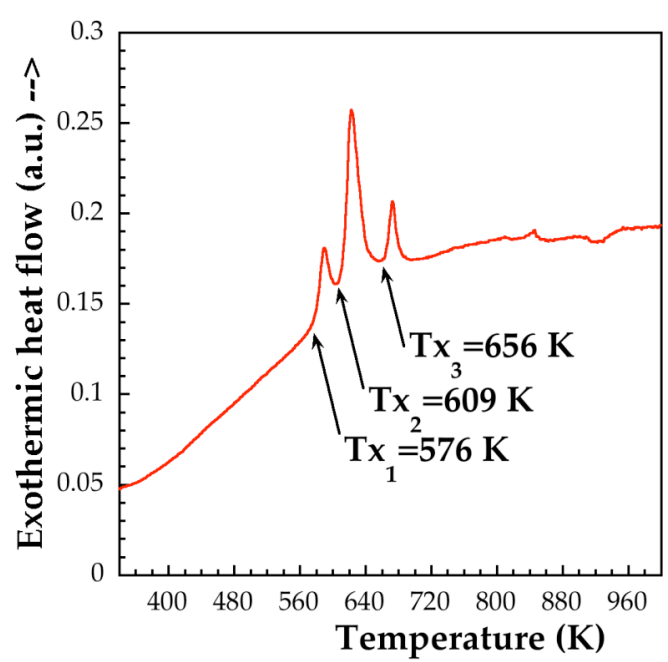

a)

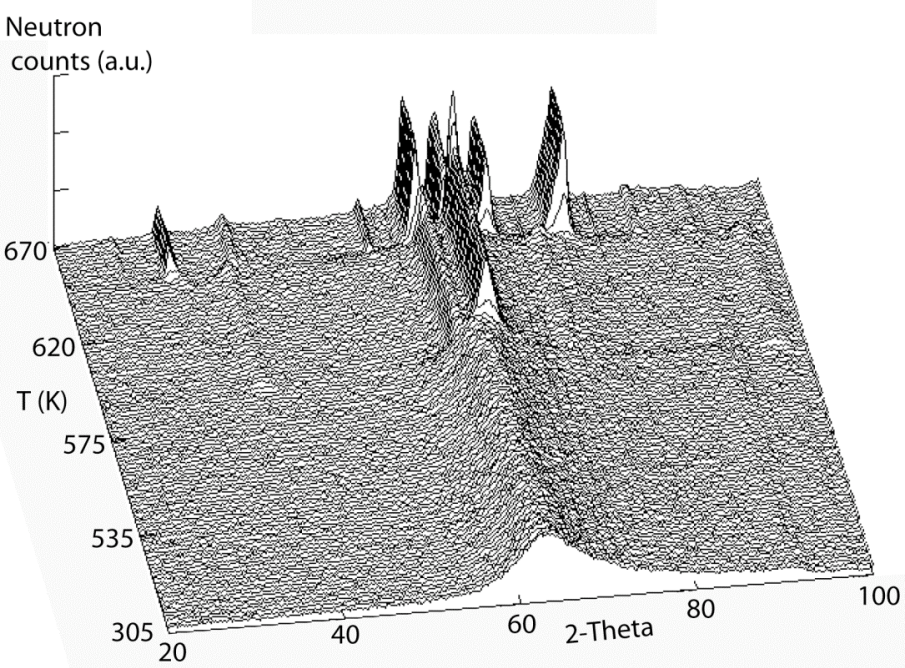

b)

Figure 1: a) DSC scan performed at $2 \mathrm{~K} / \mathrm{min}$ on the $\mathrm{Zr}_{63} \mathrm{Ti}_{14.4} \mathrm{Ni}_{12.4} \mathrm{Cu}_{10.2}$ alloy. b) $3 \mathrm{D}$ plot of the in-situ neutron diffraction experiment of the $\mathrm{Zr}_{63} \mathrm{Ti}_{14.4} \mathrm{Ni}_{12.4} \mathrm{Cu}_{10.2}$ alloy heated at $2 \mathrm{~K} / \mathrm{min}$.

At room temperature the sample is characterized by an amorphous bump centered around $\mathrm{d}=0.232$ $\mathrm{nm}$, then at $610 \mathrm{~K}$ a series of peaks appears with two main contributions at $\mathrm{d}_{1}=0.252 \mathrm{~nm}$ and $\mathrm{d}_{2}=0.239 \mathrm{~nm}$, this series of peaks disappears at $655 \mathrm{~K}$ to give new peaks that are stable up to 670 $\mathrm{K}$. The phase formed at $610 \mathrm{~K}$ is very close to the one observed in Vit4 during the crystallization experiment [10], confirming that composition determined by chemical analysis is a composition that allows preparing quasicrystals. No diffraction peak is associated to the first event $\mathrm{Tx}_{1}$ in the DSC experiment. We have then produced ribbons by increasing the content in titanium in the system $\mathrm{Zr}_{75-\mathrm{x}} \mathrm{Ti}_{\mathrm{x}} \mathrm{Ni}_{15} \mathrm{Cu}_{10}$ from $\mathrm{x}=10$ to 60 . All the ribbons have been produced in the same conditions at a constant speed of $21 \mathrm{~ms}^{-1}$. The X-ray diffraction patterns of the samples so obtained are reported in figure 2. By increasing the titanium content, the amorphous nature of the ribbons decreases up to $\mathrm{x}=25$ where peaks are appearing at positions of the quasicrystal lines observed in the previous crystallization study. By increasing the titanium content, there is a superposition of an amorphous bump and of the lines due to the quasicrystalline particles. For the composition $\mathrm{x}=60$ there is no more amorphous bump and the peak position have been indexed in the figure $3 \mathrm{a}$ with the six indices used for icosahedral phases [12].

It is also possible to produce the quasicrystalline phase by crystallization of the amorphous phase as seen in the in-situ neutron diffraction study. As an example we report in figure $3 \mathrm{~b}$ the X-ray diffraction pattern of an amorphous sample as produced by melt spinning and crystallized at $583 \mathrm{~K}$ 
during 360 minutes, but longer exposition, for example 720 minutes, or higher temperature, for example $603 \mathrm{~K}$, leads to crystallization of other phases $\left(\mathrm{Zr}_{2} \mathrm{Cu}\right)$.

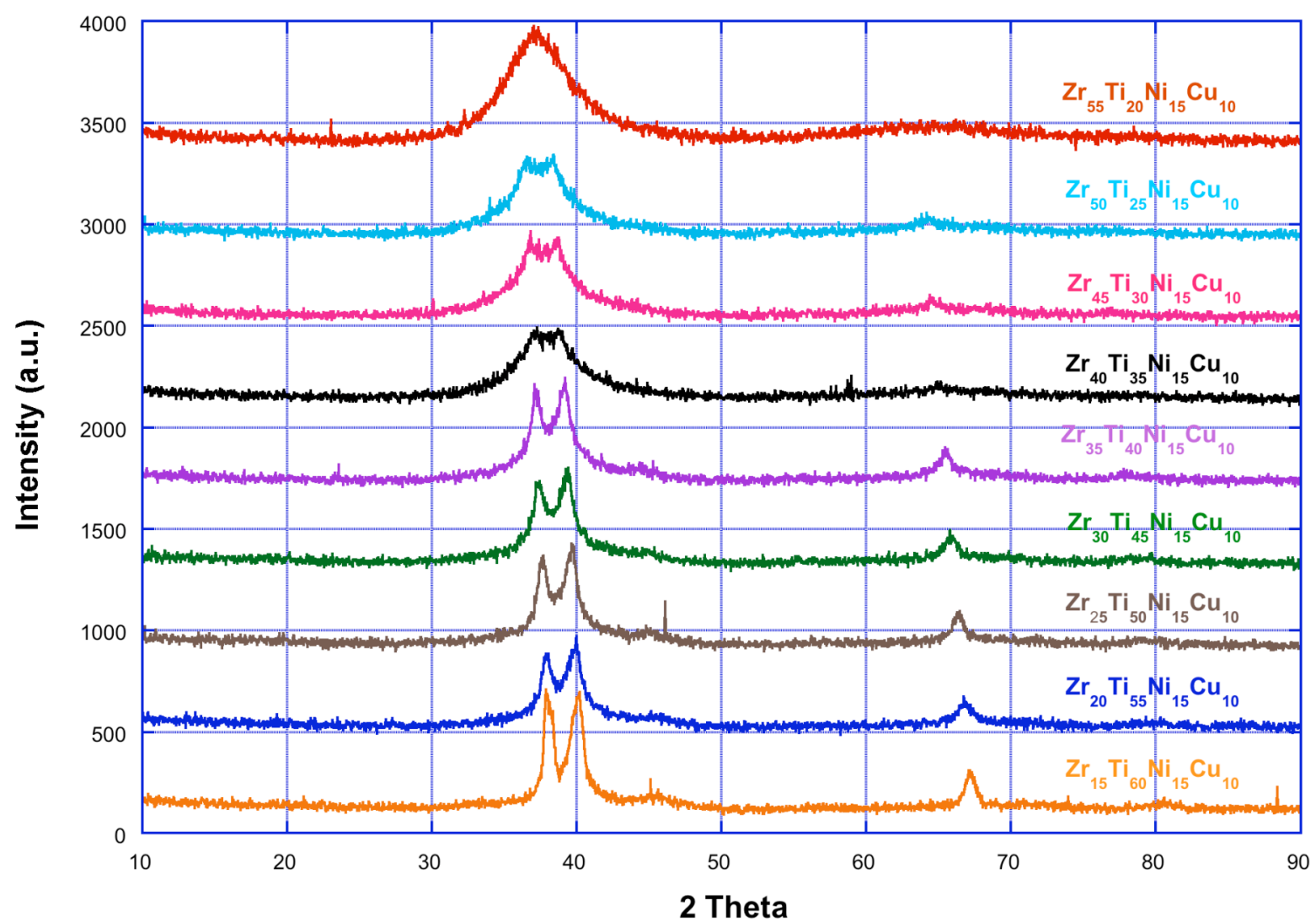

Figure 2: X-ray diffraction patterns of the phases formed directly by melt spinning in the system $\mathrm{Zr}_{75-x} \mathrm{Ti}_{x} \mathrm{Ni}_{15} \mathrm{Cu}_{15}$ from $\mathrm{x}=20$ to 60

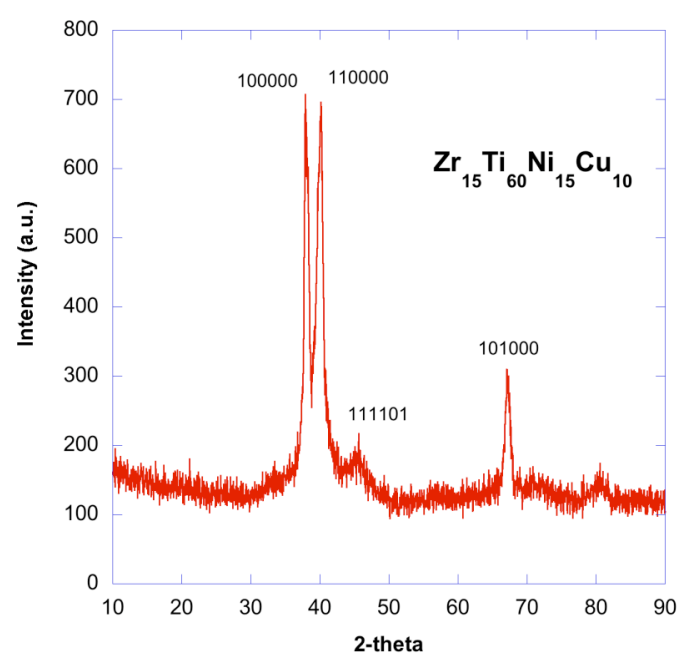

a)

Figure 3: X-ray diffraction patterns of: a) the phase formed directly by melt spinning for the alloy $\mathrm{Zr}_{15} \mathrm{Ti}_{60} \mathrm{Ni}_{15} \mathrm{Cu}_{15}$. b) The alloy $\mathrm{Zr}_{60} \mathrm{Ti}_{15} \mathrm{Ni}_{15} \mathrm{Cu} u_{15}$ after annealing at $583 \mathrm{~K}$ for 360 minutes.

On figure 2, it is possible to note that the peak positions shift to higher angles when the titanium increases, meaning that the cell parameter $\mathrm{a}_{6 \mathrm{D}}$ of the quasicrystalline lattice is decreasing when the titanium content is increasing. The lattice parameter $\mathrm{a}_{6 \mathrm{D}}$ in six-dimensional (6D) reciprocal hypercubic space, is related to the absolute diffraction vector value $Q$ by the expression: 


$$
Q=\frac{4 \pi \sin \theta}{\lambda}=\frac{2 \pi}{a_{6 D}}\left(\frac{N+M \tau}{2(2+\tau)}\right)^{1 / 2}
$$

Where $\tau$ is the irrational golden mean. The quasicrystal parameter in $3 D$ space $a_{q}$ is related to $a_{6 D}$ by the expression:

$$
a_{q}=\frac{a_{6 D}}{2^{1 / 2}}
$$

In the system studied, $\mathrm{a}_{\mathrm{q}}$ varies from $0.4673 \mathrm{~nm}$ for $\mathrm{x}=25$ to $0.4517 \mathrm{~nm}$ for $\mathrm{x}=60$.

\section{Conclusion}

The amorphous to quasicrystalline (QC) phase transformation in the $\mathrm{Zr}_{63} \mathrm{Ti}_{14.4} \mathrm{Ni}_{12.4} \mathrm{Cu}_{10.2}$ alloy has been studied by in-situ powder neutron diffraction, the transformation occurs at $610 \mathrm{~K}$, but the phase formed is metastable and decomposes at $655 \mathrm{~K}$. By changing the titanium composition in the system $\mathrm{Zr}_{75-\mathrm{x}} \mathrm{Ti}_{\mathrm{x}} \mathrm{Ni}_{15} \mathrm{Cu}_{10}$ from $\mathrm{x}=10$ to 60 , it was possible to obtain QC particles for compositions above $x=25$. The composition with the sharper peaks is $\mathrm{Zr}_{15} \mathrm{Ti}_{60} \mathrm{Ni}_{15} \mathrm{Cu}_{10}$, the alloy presents a quasilattice parameter $\mathrm{a}_{\mathrm{q}}=0.4517 \mathrm{~nm}$, close to other icosahedral QC phases as $\mathrm{Zr}_{41.5} \mathrm{Ti}_{41.5} \mathrm{Ni}_{17}$ $(0.5209 \mathrm{~nm})$ and $\mathrm{Zr}_{27} \mathrm{Ti}_{53} \mathrm{Ni}_{20}(0.5118 \mathrm{~nm})$ [13], or $0.4843 \mathrm{~nm}$ in $\mathrm{Zr}_{65} \mathrm{Al}_{7.5} \mathrm{Ni}_{10} \mathrm{Cu}_{7.5} \mathrm{Ag}_{10}$ [14]. It was also possible to produce QC phases by annealing the amorphous phases obtained for $\mathrm{x}<25$ in the system $\mathrm{Zr}_{75-\mathrm{x}} \mathrm{Ti}_{\mathrm{x}} \mathrm{Ni}_{15} \mathrm{Cu}_{10}$, but these phases have not so sharp diffraction peaks, certainly due to the relative short time possible for annealing, longer times leading to crystallization of other phases more stable as $\mathrm{Zr}_{2} \mathrm{Cu}$.

\section{Acknowledgments}

The French CNRS CRG and the Institute Laue Langevin are acknowledged for the access to the D1B spectrometer. This project has been financed by Rhône-Alpes region.

\section{References}

[1] W.L. Johnson: Mater. Sci. Forum Vol. 225-227 (1996) p. 35 ; MRS Bull. Vol. 24 (1999) p. 42 [2] N. Wanderka, M.-P. Macht, M. Seidel, S. Mechler, K. Stahl and J.Z. Jiang: Appl. Phys. Lett. Vol. 77 (2000) p. 3935

[3] M.-P. Macht, N. Wanderka, Q. Wei, I. Sieber and N. Deyneka: Mat. Sci. Eng. A Vol. 304-306 (2001) p. 701

[4] S.J. Poon, A.J. Drehman and K.R. Lawless: Phys Rev. Lett. Vol. 55 (1985) p. 2324

[5] K.F. Kelton, W.J. Kim and R.M. Stroud: Appl. Phys. Lett. Vol. 70 (1997) p. 3230

[6] J. Saida, M. Matsushita, T. Zhang, A. Inoue, M. Chen and T. Sakurai: Appl. Phys. Lett. Vol. 75 (1999) p. 3497

[7] U. Köster, J. Meinhardt, S. Roos and H. Liebertz: Appl. Phys. Lett. Vol. 69 (1996) p. 179

[8] U. Köster, D. Zander and R. Janlewing: Mat. Res. Symp. Proc. Vol. 644 (2001) L581

[9] D.V. Louzguine and A. Inoue: Appl. Phys. Lett. Vol. 78 (2001) p. 1841

[10] J.L Soubeyroux, J.M. Pelletier and B. Van de Moortèle: Mat. Res. Symp. Proc. Vol.754 (2003) p. 371

[11] B. Van de Moortèle, T. Epicier, J.L. Soubeyroux and J.M. Pelletier: Phil. Mag. Lett. Vol. 84 (2004) p. 245

[12] S. Ebalard and F. Spaepen: J. Mater. Res. Vol. 4 (1989) p. 39

[13] V. Azhazha, A. Grib, G. Khadzhay, S. Malykin, B. Merisov and A. Pugachev: Phys. Lett. A Vol. 303 (2002) p. 87

[14] J.Z. Jiang, A.R. Rasmussen, C.H. Jensen and Y. Lin: Appl. Phys. Lett. Vol. 80 (2002) p. 2090 